\title{
PENGEMBANGAN BAHAN AJAR MATA PELAJARAN BAHASA INDONESIA BERBASIS CERITA RAKYAT KABUPATEN BANJARNEGARA
}

\author{
Nia Ulfa Martha, Novita Pri Andini \\ FIB Universitas Jenderal Soedirman, Indonesia \\ Email: nia.ulfamartha@yahoo.com
}

\begin{abstract}
ABSTRAK
Penelitian ini didasarkan pada kenyataan bahwa belum tersedianya bahan ajar yang merupakan sahabat bagi guru dalam penyampaian pembelajaran bahasa Indonesia di tingkat SMA/MA kelas X semester $1 \mathrm{KD} 3.7$ dan 4.7. Tujuan dari penelitian ini adalah untuk menghasilkan bahan ajar mata pelajaran bahasa Indonesia untuk SMA kelas X semester 1 KD 3.7 dan 4.7 berbasis cerita rakyat Kabupaten Banjarnegara. Penelitian ini merupakan penelitian pengembangan dengan teknis research and development. Data dalam penelitian ini berupa skor angket berkaitan dengan kriteria-kriteria yang telah ditentukan dan data tidak terstruktur yang berupa masukan atau komentar validator. Data yang diperoleh dari angket dianalisis dengan menggunakan teknik kuantitatif sederhana dengan menghitung persentase masing-masing pertanyaan yang diberikan kepada responden. Sedangkan data kualitatif yang berupa data tidak terstruktur hasil saran dan masukan dari validator digunakan setelah diseleksi sesuai dengan kebutuhan. Menurut ahli materi, kriteria bahan ajar dikatakan valid apabila mencapai $88,5 \%$ Menurut ahli media, kriteria bahan ajar dikatakan valid apabila mencapai $80 \%$. Menurut ahli pembelajaran yakni guru bidang studi bahasa Indonesia kriteria bahan ajar dikatakan valid apabila mencapai $83,7 \%$. Berdasarkan hasil penelitian menurut peserta didik kelas X SMA Muhammadiyah Banjarnegara sebagai pengguna, bahan ajar sangat memudahkan peserta didik dalam memahami tentang cerita rakyat. Hal ini dapat dilihat dari hasil pengisian angket tentang respon peserta didik kelas $\mathrm{X}$ terhadap bahan ajar hasil pengembangan yang memiliki persentase valid $91,5 \%$. Saran-saran yang diajukan meliputi saran untuk keperluan pemanfaatan produk, desiminasi produk, dan keperluan pengembangan lebih lanjut.
\end{abstract}

Kata Kunci: Pengembangan Bahan Ajar; Bahasa Indonesia; Cerita Rakyat.

\begin{abstract}
This research was based on the fact that teaching materials are not yet adequately available as a support for teachers in delivering Bahasa Indonesia learning at the SMA (High School) / MA (Islamic High School) level in class X semester 1 of KD 3.7 and 4.7. The purpose of this research was to produce teaching materials for Bahasa Indonesia subjects for class X semesters $1 \mathrm{KD} 3.7$ and 4.7 based on Banjarnegara Regency folklore. This research is designed as a development research with a qualitative descriptive and quantitative analysis technique. The data in this research were in the form of questionnaire scores related to predetermined criteria, in addition, unstructured data were in the form of input or validator comments. Data obtained from questionnaires were analyzed by using simple quantitative techniques by calculating the percentage of each question given to respondents. While the qualitative data were in the form of unstructured data, the results of suggestions and input from the validator were used after being selected in accordance with needs. According to material experts, the criteria for teaching materials are said to be valid if the data reach $88.5 \%$. According to media experts, the criteria for teaching materials are said to be valid if they reach $80 \%$. According to the learning expert, the Indonesian language teacher, the criteria for teaching material are said to be valid if it reaches $83.7 \%$. Based on the results of research according to class X students of SMA Muhammadiyah Banjarnegara as users, this teaching
\end{abstract}


material greatly facilitates students in understanding about folklore. This statement can be seen from the results of filling out the questionnaire from class $\mathrm{X}$ students' responses to the teaching materials resulting from the development which had a percentage of validity of $91.5 \%$. Suggestions included product utilization, product dissemination, and further development needs.

Keywords: Development of Teaching Materials; Indonesian Language; Folklore.

\section{PENDAHULUAN}

Pembelajaran bahasa Indonesia khususnya sastra pada tingkat Sekolah Menengah Atas dilaksanakan melalui keterampilan mendengarkan, berbicara, membaca, dan menulis (Puspitoningrum, 2015). Keterampilan berbahasa tersebut memerlukan bahan ajar. Bahan ajar digunakan guru untuk membantu pelaksanaan kegiatan belajar mengajar. Keberadaan bahan ajar membuat guru dapat menyampaikan materi dengan baik kepada peserta didik. Selain itu, peserta didik juga menjadi lebih tertarik untuk mempelajari materi yang disampaikan oleh guru (Agung Nugroho, Lazuardi, \& Murti, 2019).

Kenyataan menunjukkan bahwa belum tersedianya bahan ajar yang merupakan sahabat bagi guru dalam penyampaian pembelajaran bahasa Indonesia di tingkat SMA/MA kelas X semester $1 \mathrm{KD} 3.7$ dan 4.7. KD 3.7 mengidentifikasi nilai-nilai dan isi yang terkandung dalam cerita rakyat (hikayat) baik lisan maupun tulis dan 4.7 menceritakan kembali isi cerita rakyat (hikayat) yang didengar dan dibaca (Sobandi, 2019). Umumnya, bahan ajar yang tersedia sementara ini disusun berdasarkan kompetensi inti dan kompetensi dasar yang tertuang dalam kurikulum terbaru. Penyajian buku belum menyentuh secara khusus tiap kompetensi dasar. Buku wajib dan buku pendamping yang ada saat ini cenderung memuat materi hikayat daripada cerita rakyat. Dengan demikian, hasil pengembangan ini dimaksudkan untuk memenuhi tersedianya bahan ajar yang memuat materi cerita rakyat sebagai pendamping bagi guru dalam penyampaian pembelajaran bahasa Indonesia di tingkat SMA/MA kelas X semester 1 KD 3.7 dan 4.7 khususnya untuk sekolah-sekolah di Kabupaten Banjarnegara.

Cerita rakyat merupakan materi yang terdapat dalam bahan ajar SMA kelas $\mathrm{X}$ semester $1 \mathrm{KD} 3.7$ dan 4.7. Cerita rakyat yang digunakan dalam bahan ajar ini adalah cerita rakyat dari Kabupaten Banjarnegara. Cerita rakyat Kabupaten Banjarnegara adalah genre sastra lisan yang disampaikan dan diwariskan secara 
turun-temurun dari generasi ke generasi yang harus dilestarikan atau dipertahankan keberadaannya di tengah-tengah masyarakat (Youpika \& Zuchdi, 2016). Cerita rakyat Kabupaten Banjarnegara dapat meningkatkan nilai-nilai karakter yang dimiliki peserta didik (Komariah, 2018). Karakter adalah tabiat, kepribadian, identitas diri, dan jatidiri (Nurgiyantoro, 2011). Nilai-nilai karakter yang terkandung dalam cerita rakyat tersebut dapat digunakan guru dalam mengembangkan karaktersitik peserta didik yang sesuai dengan cita-cita bangsa dan negara Indonesia. Selain itu, materi cerita rakyat ini dapat mengembangkan kelestarian kebudayaan daerah. Bahan ajar yang dikembangkan dengan mempertimbangkan karakteristik dan lingkungan sekitar peserta didik akan lebih efektif meningkatkan pengetahuan dan kemampuan memahami lingkungan secara arif bagi peserta didik (Tang, Jufri, \& Sultan, 2015).

Kabupaten Banjarnegara merupakan salah satu daerah yang memiliki kekayaan budaya. Budaya tersebut berupa kesenian, bahasa, cerita rakyat, falsafah, dan sebagainya. Keanekaragaman budaya menjadi cerminan nilai-nilai yang dianut pada masyarakat tersebut (Siska, 2015). Kebudayaan yang tumbuh dan berkembang di daerah harus senantiasa dijaga untuk melestarikan kearifan lokal. Oleh karena itu, pembelajaran bahasa Indonesia untuk SMA kelas X semester 1 KD 3.7 dan 4.7 dapat menggunakan bahan ajar cerita rakyat berbasis kearifan lokal (Kabupaten Banjarnegara). Cerita rakyat yang disajikan dalam bahan ajar memiliki kedekatan kultur dengan masyarakat di Kabupaten Banjarnegara. Selain itu, cerita rakyat ini dapat meningkatkan nilai-nilai positif karakter yang dimiliki peserta didik. Tidak hanya itu, peserta didik menjadi lebih mudah mempelajari materi yang disampaikan karena dekat dengan lingkungannya. Cerita rakyat juga dapat diterapkan di wilayah lain dengan disesuaikan cerita rakyat yang berkembang di wilayah setempat.

Tujuan dari penelitian ini adalah untuk menghasilkan bahan ajar mata pelajaran bahasa Indonesia untuk SMA kelas X semester 1 KD 3.7 dan 4.7 berbasis cerita rakyat Kabupaten Banjarnegara. Asep dkk. (2012:4) mengatakan bahwa "bahan pembelajaran merupakan seperangkat materi atau substansi pelajaran yang disusun secara runtut dan sistematik serta menampilkan sosok utuh dari kompetensi yang akan dikuasai peserta didik dalam kegiatan pembelajaran”. Fungsi bahan ajar dapat dibedakan menjadi dua macam, yaitu fungsi bagi pendidik dan fungsi bagi 
peserta didik (Prastowo, 2011). Selanjutnya jenis bahan ajar yang dibedakan menjadi empat macam, yaitu bahan cetak, bahan ajar dengar, bahan ajar pandang dengar, dan bahan ajar interaktif (Prastowo, 2011). Kepatutan satu buah bahan pelajaran wajib mempunyai ukuran sebagai berikut (1) self instructional, melalui bahan ajar siswa dapat membelajarkan dirinya sendiri, (2) self contained, di dalam bahan ajar harus berisi satu kesatuan materi yang utuh, (3) stand alone, bahan ajar yang dikembangkan bisa digunakan sendiri tanpa harus melibatkan bahan ajar yang lain, (4) adaptive, bahan ajar hendaknya menyesuaikan dengan perkembangan teknologi yang ada serta sesuai dengan kurikulum yang berlaku, dan (5) user friendly, bahan ajar haruslah sesuai dengan perkembangan penggunanya sehingga peserta didik dapat dengan mudah memahami isi bahan ajar tersebut (Widodo \& Jasmadi, 2008).

Bahan ajar yang dimaksud adalah bahan ajar yang memuat materi yang mendekatkan peserta didik dengan lingkungan sekitarnya. Materi yang mendekatkan pada peserta didik akan mudah dipahami karena berkaitan dengan kehidupan sehari-hari. Salah satu teks yang wajib diajarkan dalam Kurikulum 2013 pada tingkat SMA/MA adalah teks cerita rakyat. Teks ini bertujuan untuk mengajak peserta didik menceritakan kembali isi yang terkandung dalam cerita rakyat. Berdasarkan hal tersebut, peneliti termotivasi untuk melakukan pengembangan mata pelajaran bahasa Indonesia berbasis cerita rakyat Kabupaten Banjarnegara. Penelitian ini juga mengacu pada tiga masalah diantaranya adalah, (1) mengembangkan bahan ajar yang praktis dan inovatif yang sesuai dengan kebutuhan dan permintaan budaya lokal/kedaerahan setempat, (2) pemilihan teks cerita rakyat dikarenakan peserta didik pada saat sekarang tidak mengenal cerita rakyat disekitarnya, karena sekolah ini bertempat di Kabupaten Banjarnegara maka sudah selayaknya peserta didik mengetahui cerita rakyat-cerita rakyat tersebut, dan (3) pembelajaran teks cerita rakyat di buku terlalu meluas sehingga peserta didik tersebut lupa atau tidak peka dengan yang ada didekatnya (Afifah, 2019). Pembelajaran bahasa Indonesia adalah bagian dari Kurikulum 2013 yang menekankan pentingnya keseimbangan kompetensi sikap, pengetahuan, dan keterampilan. Kemampuan berbahasa dituntut mampu menjadi pembelajaran berkelanjutan karena bahasa Indonesia menjadi ujung tombak mata pelajaran 
lainnya. Berdasarkan hal tersebut, pembelajaran bahasa Indonesia dimulai dengan meningkatkan pengetahuan tentang jenis, kaidah dan konteks suatu teks, dilanjutkan dengan keterampilan menyajikan suatu teks tulis dan lisan (Soraya, 2014).

Penelitian yang berhubungan dengan pengembangan bahan ajar sebelumnya sudah banyak dilakukan oleh peneliti lain. Penelitian tersebut tentu masih memiliki kekurangan sehingga perlu adanya penelitiaan lanjutan (Owon, 2017). Penelitianpenelitian tersebut diantaranya adalah penelitian Mahcmuda (2013) dengan judul "Pengembangan Bahan Ajar Membaca Cerita Anak Berbasis Cerita Rakyat Jawa Timur untuk Siswa Kelas V MI Nurul Huda Malang”. Hasil penelitian menunjukkan menurut ahli materi bahan ajar dikatakan valid apabila mencapai $77,4 \%$, menurut ahli media bahan ajar dikatakan valid apabila mencapai 70\%, menurut ahli pembelajaran bahan ajar dikatakan valid apabila mencapai $72,6 \%$, dan menurut peserta didik bahan ajar dikatakan valid apabila mencapai 80,4\%. Selanjutnya, (Azis \& Hajrah, 2015) dengan judul "Dongeng sebagai Bahan Pembelajaran Bahasa dan Sastra Indonesia di Sekolah Dasar". Hasil penelitian menunjukkan bahwa secara umum rerata penilaian responden kesesuaian aspek isi cerita rakyat kategori dongeng dengan bahan ajar pembelajaran bahasa dan sastra Indonesia di Sekolah Dasar adalah 3,92 atau pada kategori layak dijadikan bahan ajar. Penelitian (Juwita, 2018) dengan judul "Pengembangan Bahan Ajar Sastra Berbasis Cerita Rakyat Asal Usul Way Linti dan Asal Usul Kuto Bumi untuk Pembelajaran Nilai-Nilai Karakter Siswa Kelas VII SMP”. Hasil penelitian menunjukkan bahwa (1) telah berhasil dikembangkan buku berupa materi ajar sastra cerita rakyat Asal Usul Way Linti dan Asal Usul Kuto Bumi dengan judul buku “Apresiasi Legenda Asal Usul Way Linti dan Asal Usul Kuto Bumi”, dan (2) hasil penelitian kelayakan buku materi ajar secara keseluruhan dinyatakan "Sangat Layak" oleh penilaian 1 ahli materi, 3 guru bahasa dan sastra Indonesia, dan 30 siswa SMP kelas VII dari 3 sekolah 10 siswa yaitu SMP Negeri 01 Pardsuka, SMP Negeri 01 Ambarawa, dan SMP Negeri 02 Pringsewu.

Penelitian-penelitian di atas memaparkan hal-hal yang berkaitan dengan pengembangan bahan ajar cerita rakyat. Penelitian ini dilakukan sebagai inovasi untuk pengembangan bahan ajar mata pelajaran bahasa Indonesia berbasis cerita 
rakyat Kabupaten Banjarnegara yang belum pernah ada dalam penelitian-penelitian dan pembelajaran sebelumnya.

\section{METODE}

Metode yang digunakan dalam penelitian ini adalah metode penelitian dan pengembangan atau Research and Development yang digunakan untuk menghasilkan produk tertentu dan menguji keefektifan, keefisiensi dan kemenarikan produk tersebut. Untuk dapat menghasilkan produk tertentu digunakan penelitian yang bersifat analisis kebutuhan dan untuk menguji keefektifan produk tersebut supaya dapat berfungsi di masyarakat luas, maka diperlukan penelitian untuk menguji keefektifan produk tersebut. Jadi penelitian dan pengembangan bersifat longitudinal atau bertahap. Dari model penelitian yang dilakukan Borg and Gall tersebut, peneliti mengadaptasinya sebagai berikut: 1) tahap persiapan, 2) tahap pengembangan produk, 3) tahap uji coba produk, dan 4) tahap revisi produk.

Subjek uji coba dalam pengembangan bahan ajar mata pelajaran bahasa Indonesia untuk kelas $\mathrm{X}$ semester $1 \mathrm{KD} 3.7$ dan 4.7 berbasis cerita rakyat Kabupaten Banjarnegara ini adalah ahli materi, ahli media pembelajaran, guru bidang studi bahasa Indonesia kelas X SMA sebagai ahli pembelajaran bahasa Indonesia, dan peserta didik kelas X SMA Muhammadiyah Banjarnegara. Pemilihan SMA Muhammadiyah Banjarnegara sebagai lokasi uji coba didasarkan pada beberapa alasan, yaitu: 1) peserta didik mengalami kesulitan mempelajari materi mengidentifikasi nilai-nilai dan isi yang terkandung dalam cerita rakyat (hikayat) baik lisan maupun tulis dan menceritakan kembali isi cerita rakyat (hikayat) yang didengar dan dibaca, 2) belum mempunyai bahan ajar bahasa Indonesia dengan berbasis cerita rakyat Kabupaten Banjarnegara, dan 3) kemampuan peserta didik beragam.

Instrumen penelitian utama yang digunakan untuk mengumpulkan data pada penelitian ini adalah draf bahan ajar, sedangkan instrumen pendukungnya berupa angket atau kuesioner. Kuesioner adalah sejumlah pertanyaan tertulis yang digunakan untuk memperoleh informasi dari responden dalam arti laporan tentang pribadinya, atau hal-hal yang diketahuinya. Dalam penelitian ini jenis kuesioner 
yang digunakan adalah kuesioner tertutup, yaitu kuesioner yang sudah disediakan jawabannya sehingga tinggal memilih jawaban yang sesuai dengan membubuhkan tanda tertentu pada kolom jawaban yang disediakan. Angket yang digunakan adalah jenis angket yang berisi rating scale. Kuesioner (angket) rating scale adalah angket yang berisikan pertanyaan yang diikuti kolom-kolom yang menunjukkan tingkatantingkatan.

Data yang diperoleh dari kuesioner dianalisis dengan menggunakan teknik kuantitatif sederhana dengan menghitung persentase jawaban masing-masing item pertanyaan yang diberikan kepada responden. Data kualitatif yang berupa data tidak terstruktur (data verbal) digunakan setelah diseleksi sesuai dengan kebutuhan.

Berdasarkan kriteria yang ditentukan, bahan ajar dinyatakan valid jika memenuhi kriteria skor 80 dari seluruh unsur yang terdapat dalam angket penilaian validasi ahli media, ahli materi, guru bidang studi bahasa Indonesia SMA dan peserta didik kelas X SMA. Dalam pengembangan ini, bahan ajar yang dibuat harus memenuhi kriteria valid. Oleh karena itu, dilakukan revisi apabila bahan ajar masih belum memenuhi kriteria valid.

\section{HASIL DAN PEMBAHASAN}

Hasil dari penelitian ini merupakan inovasi pengembangan materi pembelajaran yang pertama kali dilakukan dengan menggunakan 4 tahap validasi berupa data penilaian produk pengembangan bahan ajar yang dilakukan dalam empat tahap: (1) Tahap pertama diperoleh dari hasil penilaian terhadap produk pengembangan bahan ajar yang dilakukan oleh satu dosen Pendidikan Bahasa dan Sastra Indonesia (PBSI) sebagai ahli materi ilmu bahasa Indonesia, (2) tahap kedua diperoleh dari hasil penilaian terhadap produk pengembangan bahan ajar yang dilakukan oleh satu dosen PBSI sebagai ahli media, (3) tahap ketiga diperoleh dari hasil penilaian terhadap produk pengembangan bahan ajar yang dilakukan oleh satu guru bidang studi bahasa Indonesia kelas X SMA sebagai ahli pembelajaran, dan (4) tahap keempat diperoleh dari hasil validasi terhadap produk pengembangan bahan ajar yang dilakukan pada uji coba lapangan. Evaluasi dilakukan melibatkan pakar karakter, pakar pendidikan, pakar desain grafis, dan pengguna bahan ajar (guru dan peserta didik). 


\section{Hasil Validasi Ahli Materi}

Produk pengembangan yang diserahkan kepada ahli materi mata pelajaran bahasa Indonesia adalah berupa bahan ajar. Asep dkk. (2012:4) mengatakan bahwa bahan pembelajaran merupakan seperangkat materi atau substansi pelajaran yang disusun secara runtut dan sistematik serta menampilkan sosok utuh dari kompetensi yang akan dikuasai peserta didik dalam kegiatan pembelajaran. Sementara itu, bahan ajar adalah bahan yang digunakan untuk membantu guru dalam melaksanakan kegiatan belajar mengajar.

Paparan deskriptif hasil validasi ahli materi bahasa Indonesia terhadap produk pengembangan bahan ajar bahasa Indonesia untuk kelas $\mathrm{X}$ semester $1 \mathrm{KD}$ 3.7 dan 4.7 berbasis cerita rakyat Kabupaten Banjarnegara diajukan melalui metode kuesioner dengan instrumen angket. Hasil validasi ahli materi bahasa Indonesia terhadap produk pengembangan bahan ajar mata pelajaran bahasa Indonesia untuk kelas X semester $1 \mathrm{KD} 3.7$ dan 4.7 berbasis cerita rakyat Kabupaten Banjarnegara adalah 69,2 \% menyatakan valid, 15,4\% menunjukkan tingkat validitas cukup valid, dan 15,4 \% menunjukkan tingkat validitas kurang valid. Hal ini sejalan dengan penelitian (Aji, Suwignyo, dan Maryaeni, 2017) yang menunjukkan hasil uji ahli komponen materi bahan ajar ini yang mendapatkan nilai rata-rata 93. Selain penilaian dalam bentuk angka, ahli materi juga memberikan catatan berupa komponen penyajian materi pembelajaran untuk KD memerankan belum sepenuhnya dapat mendukung kegiatan pembelajaran sehingga perlu pembenahan pada bagian KD memerankan agar dapat digunakan untuk mendukung seluruh kegiatan pembelajaran dalam bahan ajar. Ahli materi juga memberikan catatan berupa jumlah materi yang terlalu banyak dalam bab berkenalan dengan legenda sehingga jumlahnya perlu disesuaikan dengan waktu yang diperlukan untuk menguasai KD memerankan dalam bahan ajar.

Semua data dari hasil review, penilaian dan diskusi dengan ahli materi bahasa Indonesia dijadikan landasan untuk merevisi guna penyempurnaan komponen bahan ajar dan materi mata pelajaran bahasa Indonesia sebelum diuji cobakan pada peserta didik pengguna bahan ajar produk pengembangan.

Dari angket tanggapan yang diisi oleh ahli materi, dapat dihitung persentase tingkat kevalidan bahan ajar. Hasil persentase sebesar 88,5\%. Sesuai dengan tabel 
konversi skala, persentase tingkat pencapaian $88,5 \%$ berada pada kualifikasi valid sehingga bahan ajar tidak perlu dilakukan revisi.

\section{Hasil Validasi Ahli Media Pembelajaran}

Produk pengembangan yang diserahkan kepada ahli media pembelajaran adalah berupa bahan ajar. Paparan deskriptif hasil validasi ahli media pembelajaran terhadap produk pengembangan bahan ajar bahasa Indonesia untuk kelas $\mathrm{X}$ semester 1 KD 3.7 dan 4.7 berbasis cerita rakyat Kabupaten Banjarnegara yang diajukan melalui metode kuesioner dengan instrumen angket. Hasil validasi ahli media pembelajaran terhadap produk pengembangan bahan ajar mata pelajaran bahasa Indonesia untuk kelas X semester 1 KD 3.7 dan 4.7 berbasis cerita rakyat Kabupaten Banjarnegara adalah 27\% menyatakan valid, 67\% menunjukkan tingkat validitas cukup valid, dan 6\% menyatakan kurang valid. Pada penelitian (Aji, Suwignyo, dan Maryaeni, 2017) produk pengembangan diserahkan kepada ahli komponen kegrafikan. Hasil uji ahli komponen kegrafikan bahan ajar ini mendapatkan nilai rata-rata 87. Dalam penilaian ahli komponen kegrafikan juga memberikan nilai 60 pada indikator (2) yaitu kemenarikan sampul sesuai dengan tingkat perkembangan peserta didik. Sehingga diperlukan revisi agar sampul menarik sesuai dengan tingkat perkembangan peserta didik.

Semua data dari hasil review, penilaian dan diskusi dengan ahli media pembelajaran dijadikan landasan untuk merevisi guna penyempurnaan desain bahan ajar bahasa Indonesia sebelum diuji cobakan pada peserta didik pengguna bahan ajar produk pengembangan.

Dari angket tanggapan yang diisi oleh ahli media pembelajaran, dapat dihitung persentase tingkat kevalidan bahan ajar. Hasil persentase sebesar $80 \%$. Sesuai dengan tabel konversi skala, persentase tingkat pencapaian $80 \%$ berada pada kualifikasi valid dan baik sehingga bahan ajar tidak perlu dilakukan revisi. Hal ini menunjukkan bahwa bahan ajar mata pelajaran bahasa Indonesia untuk kelas $\mathrm{X}$ semester 1 KD 3.7 dan 4.7 berbasis cerita rakyat Kabupaten Banjarnegara sudah baik dan layak untuk digunakan menurut ahli media pembelajaran. 


\section{Hasil Validasi Guru Bidang Studi Bahasa Indonesia Kelas X SMA}

Produk pengembangan yang diserahkan kepada guru bidang studi bahasa Indonesia kelas X SMA adalah berupa bahan ajar. Paparan deskriptif hasil validasi guru bidang studi bahasa Indonesia terhadap produk pengembangan bahan ajar mata pelajaran bahasa Indonesia untuk kelas X semester $1 \mathrm{KD} 3.7$ dan 4.7 berbasis cerita rakyat Kabupaten Banjarnegara yang diajukan melalui metode kuesioner dengan instrumen angket. Hasil penilaian guru bidang studi bahasa Indonesia terhadap produk pengembangan bahan ajar yaitu, 45\% menyatakan valid, 45\% menunjukkan tingkat validitas cukup valid, dan 10\% menunjukkan tingkat validitas kurang valid. Pada penelitian (Aji, Suwignyo, dan Maryaeni, 2017) produk pengembangan diserahkan kepada ahli komponen pembelajaran. Hasil uji ahli komponen pembelajaran bahan ajar ini mendapatkan nilai rata-rata 87. Dalam penilaian ahli komponen pembelajaran juga memberikan nilai 60 pada indikator (4) yaitu pelaksanaan pembelajaran menyusun naskah drama dan indikator (5) dalam aspek pendukung pelajaran yaitu kesesuaian pemilihan gambar, ukuran serta warna gambar. Sehingga indikator tersebut harus melalui proses revisi sebelum di uji cobakan di lapangan.

Semua data dari hasil review, penilaian dan diskusi dengan guru bidang studi bahasa Indonesia kelas X SMA dijadikan landasan untuk merevisi guna penyempurnaan isi bahan ajar bahasa Indonesia sebelum di uji cobakan pada peserta didik pengguna bahan ajar produk pengembangan.

Dari angket tanggapan yang diisi oleh guru bidang studi bahasa Indonesia kelas X SMA Muhammadiyah Banjarnegara sebagai ahli pembelajaran bidang bahasa Indonesia, dapat dihitung persentase tingkat kevalidan bahan ajar. Hasil persentase sebesar $83,7 \%$. Sesuai dengan tabel konversi skala, persentase tingkat pencapaian $83,7 \%$ berada pada kualifikasi valid sehingga bahan ajar tidak perlu dilakukan revisi. Hal ini menunjukkan bahwa bahan ajar mata pelajaran bahasa Indonesia untuk kelas $\mathrm{X}$ semester $1 \mathrm{KD} 3.7$ dan 4.7 berbasis cerita rakyat Kabupaten Banjarnegara sudah baik dan layak untuk digunakan menurut guru bidang bahasa Indonesia kelas X SMA. 


\section{Hasil Uji Coba Lapangan}

Produk pengembangan yang diserahkan untuk uji coba lapangan pembelajaran bahasa Indonesia adalah berupa bahan ajar. Produk pengembangan diserahkan kepada uji coba lapangan yang terdiri dari 29 koresponden. Hasil penilaian uji coba lapangan terhadap produk pengembangan bahan ajar yaitu $100 \%$ menyatakan valid.

Data kualitatif yang dihimpun dari masukan, saran dan komentar uji coba lapangan dalam pernyataan terbuka berkenaan dengan produk bahan ajar yang telah diuji cobakan adalah sebagai berikut: (a) Tampilan buku sudah bagus dan menarik; (b) Buku ini sangat memudahkan siswa untuk mempelajari tentang unsur-unsur cerita; dan (c) Buku ini memotivasi siswa untuk belajar.

Hasil validasi bahan ajar pada uji coba lapangan terhadap pengembangan bahan ajar mata pelajaran bahasa Indonesia untuk kelas X semester 1 KD 3.7 dan 4.7 berbasis cerita rakyat Kabupaten Banjarnegara dinilai baik dengan prosentase 91,5\% dari kriteria yang ditetapkan. Hasil persentase sebesar $91,5 \%$ berada pada kualifikasi valid sehingga bahan ajar tidak perlu dilakukan revisi. Hal ini menunjukkan bahwa bahan ajar bahasa Indonesia kelas X SMA materi cerita rakyat Kabupaten Banjarnegara sudah baik dan layak untuk digunakan dalam proses pembelajaran.

\section{SIMPULAN}

Dari proses pengembangan yang dilakukan, telah dihasilkan bahan ajar bahasa Indonesia berbasis cerita rakyat Kabupaten Banjarnegara untuk peserta didik kelas X SMA. Bahan ajar ini hanya dapat digunakan di Kabupaten Banjarnegara dan sekitarnya. Secara umum materi dapat digunakan di daerah lain dengan menyesuaikan cerita rakyat yang berkembang di wilayah setempat. Mengingat KD 3.7 dan 4.7 berlaku secara umum. Bahan ajar ini berisi materi-materi pembelajaran cerita rakyat. Bagian-bagian materi bahan ajar ini meliputi bagian pendahuluan, bagian isi, dan bagian penutup. Bahan ajar yang dihasilkan yaitu berupa produk buku. Proses pengembangan bahan ajar ini dilakukan semaksimal mungkin agar bahan ajar yang dihasilkan meminimalkan kelemahan-kelemahan 
yang mungkin timbul. Saran-saran yang diajukan meliputi saran untuk keperluan pemanfaatan produk, diseminasi produk, dan keperluan pengembangan lebih lanjut.

\section{DAFTAR PUSTAKA}

Afifah, E. R. (2019). Pengembangan Bahan Ajar Teks Biografi dengan Aplikasi Adobe Flash pada Siswa Kelas X SMA 02 Diponegoro Jember. Beranda, 7(2). Agung Nugroho, Lazuardi, D., \& Murti, S. (2019). Pengembangan Bahan Ajar LKS Menulis Pantun Berbasis Kearifan Lokal Siswa Kelas VII SMP Xaverius Tugumulyo. KEMBARA: Jurnal Keilmuan Bahasa, Sastra, Dan Pengajarannya, 5(1), 1--12. https://doi.org/10.22219/kembara.vol5.no1.1-12 Azis, A., \& Hajrah. (2015). Dongeng sebagai Bahan Pembelajaran Bahasa dan Sastra Indonesia di Sekolah Dasar. Seminar Nasional UNM, 19--31. Juwita, A. (2018). Pengembangan Bahan Ajar Sastra Berbasis Cerita Rakyat Asal

Usul Way Linti dan Asal Usul Kuto Bumi untuk Pembelajaran Nilai-Nilai $\begin{array}{lllll}\text { Karakter } & \text { Siswa } & \text { Kelas } & \text { VII }\end{array}$ https://doi.org/10.1017/CBO9781107415324.004

Komariah, Y. (2018). Pengembangan Bahan Ajar Cerita Rakyat Kuningan Terintegrasi Nilai Karakter dalam Pembelajaran Apresiasi Sastra di SMP. Deiksis-Jurnal Pendidikan Bahasa Dan Sastra Indonesia, 5(1), 100--110. https://doi.org/10.1017/CBO9781107415324.004

Nurgiyantoro, B. (2011). Wayang dan Pengembangan Karakter Bangsa. Jurnal Pendidikan Karakter, 1(1), 18--34. https://doi.org/10.21831/jpk.v1i1.1314

Owon, R. A. S. (2017). Pengembangan Bahan Ajar Menulis Berbagai Jenis Teks Bertema Kearifan Lokal Sikka Bagi Siswa SMP. JINoP (Jurnal Inovasi Pembelajaran), 3(1), 528--541. https://doi.org/10.22219/jinop.v3i1.4318

Prastowo, A. (2011). Metode Penelitian Kualitatif dalam Perspektif Rancangan Penelitian. Yogyakarta: Ar-Ruzz Media.

Puspitoningrum, E. (2015). Pengembangan Bahan Ajar Menulis Kembali Dongeng untuk Siswa SMP Kelas VII. KEMBARA: Jurnal Keilmuan Bahasa, Sastra, Dan Pengajarannya, 1(2), 152--162.

Siska, Y. (2015). Analisis Kebutuhan Bahan Ajar Sejarah Lokal Lampung Untuk Sekolah Dasar. Mimbar Sekolah Dasar, 2(2), 199--211. 
https://doi.org/10.17509/mimbar-sd.v2i2.1330

Sobandi. (2019). Bahasa Indonesia untuk SMA/MA Kelas X. Jakarta: Erlangga.

Soraya, A. (2014). Pengembangan Bahan Ajar Teks Prosedur Kompleks dalam Pembelajaran Bahasa Indonesia untuk Kelas X SMK. NOSI, 2(2), 13--28.

Tang, M. R., Jufri, \& Sultan. (2015). Pengembangan Bahan Ajar Cerita Fiksi Berbasis Wacana Budaya di Sekolah Dasar. Jurnal Pendidikan Dan Pembelajaran, 22(2), 169--175.

Widodo, C. S., \& Jasmadi. (2008). Panduan Menyusun Bahan Ajar Berbasis Kompetensi. Jakarta: PT Elex Media Kompetindo.

Youpika, F., \& Zuchdi, D. (2016). Nilai Pendidikan Karakter Cerita Rakyat Suku Pasemah Bengkulu dan Relevansinya sebagai Materi Pembelajaran Sastra. Jurnal Pendidikan Karakter, 6(1), 48--58. https://doi.org/10.21831/ jpk.v0i1.10731 